\title{
Caddo Pottery in Modern and Contemporary Art and Protection of Native American Cultures in Fine Arts by the IACB's Indian Arts and Crafts Act
}

Chase K. Earls

Unknown

Follow this and additional works at: https://scholarworks.sfasu.edu/ita

Part of the American Material Culture Commons, Archaeological Anthropology Commons, Environmental Studies Commons, Other American Studies Commons, Other Arts and Humanities Commons, Other History of Art, Architecture, and Archaeology Commons, and the United States History Commons

Tell us how this article helped you.

This Article is brought to you for free and open access by the Center for Regional Heritage Research at SFA ScholarWorks. It has been accepted for inclusion in Index of Texas Archaeology: Open Access Gray Literature from the Lone Star State by an authorized editor of SFA ScholarWorks. For more information, please contact cdsscholarworks@sfasu.edu. 


\section{Caddo Pottery in Modern and Contemporary Art and Protection of Native American Cultures in Fine Arts by the IACB's Indian Arts and Crafts Act}

\section{Creative Commons License}

\section{(c) (1) \&}

This work is licensed under a Creative Commons Attribution-NonCommercial 4.0 International License 


\section{CAddo Pottery in Modern and Contemporary Art And Protection of Native American Cultures in Fine ARts by THE IACB'S INDIAN ARTS AND CRAFTS ACT}

\section{Chase Kawinhut Earles}

Hello, my name is Chase Kawinhut Earles. I was named by Julia Edge, daughter of Pauline Washington, who was the granddaughter of the Caddo chief, George Washington. I recently, well, not that very long ago started creating Caddo pottery with the much appreciated guidance from Jeri Redcorn. I have been an artist all my life, but mostly only a painter, not much clay, sculpture or pottery. I was inspired to create pottery though, but my experiences were with the Southwest and the Pueblo artists, as this is what I grew up around and what I learned. But I never started. I never found any inspiration. I realized one day it was because I am not a Pueblo Indian and creating Pueblo or Southwest pottery would, to me, feel hollow. I would feel as though I was just creating knock-offs or replications, and not truly inspired or authentic art. This beginning is what defines me and my ideas about Native American Art. Jeri Redcorn and I are two of only maybe a few active Caddo traditional potters. As we work to revive our long tradition and heritage of pottery we have started to unfold an ancient legacy that has proven to be very unique among other native cultures.

However, as we progress in the awareness of this legacy, not only for the pride of our young ones that are growing up learning the Caddo ways, but also so that we might begin to construct a base of financial return for those that choose to continue the ways, we have found that we are running into a lot of individuals that are destroying what consumer confidence we may build up by copying, replicating, and knocking-off our very unique style of pottery for their own personal gain.

Now, this does have to do with Caddo Fine Arts and Arts \& Crafts, but as I am involved more and learn more about this I am starting to see that Native Arts and archaeology are sometimes very much intertwined.

I know a lot of people are looking to the overseas replicating of Native arts being imported here, but they are then overlooking the very real issue that we have at home with people and even Native people defrauding other tribes to which they don't belong. We have sought recourse by contacting the Indian Arts and Crafts Board of the Department of the Interior, but they have revealed to us a very severe flaw in their laws-a loophole by which any Native person can copy any other tribes' art style or traditional heritage. How is this any different from people overseas knocking-off our art? It accomplishes the same exact thing. It destroys consumer confidence. Consumers will have no faith and no trust in what any Southeast Native American would try to sell them is authentic, citing that we don't even know what is of our own tribe and what is not. As if we just make things up and copy anything that suits our fancy.

For example: We had a Native potter, that is not Caddo, copy Caddo pottery claiming that the "Caddoan" pottery he creates is also the heritage of his tribe, because it is Mississippian, so that he has the right to copy it as his own tribe's work. He goes so far as to claim that no one really knows what is Caddo, and what is not.

This is where archaeology does get involved. This artist claims that his references are anthropologists and archaeologists he knows- "friends and acquaintances." 
Also, I have heard mention of individuals with no discernable Native blood, who sometimes claim the heritage, creating and selling Caddo pottery, that should be warned of the laws of the Indian Arts and Crafts Act. This is not to discredit or dissuade anyone, like archaeologists or educators, from making Caddo pottery for science, experimentation, replication for museums, or for their own enjoyment. But it should be a warning for those people that make this pottery and try to sell it in shows, exhibitions, festivals, and competitions as modern Caddo pottery.

Some people have no afore knowledge of the laws of the Indian Arts and Crafts Act. Some people that have heard of it usually quote the old outdated law, or they try to make sense of the very new bylaws of the Act, that I have right here. In the end, the Act only states that if you are going to use any word describing any tribe whatsoever, if you are not in that tribe, you have to put the word "style" or "like" or "inspired" in the title.

Here is where the flaw is. The law doesn't actually discern what is Hopi, or what is Caddo, or what is Cherokee. It simply states that the artist must title the work "appropriately." So, if that artist understands the loophole, then they can call the Cherokee pot a Seminole pot, for example, and if the artist was Seminole then no one could do anything about it. A Native Artist can essentially call his work his tribe's work and the law cannot even begin to approach whether he or she is telling the truth or whether it is factual. The law actually even states that it is not within its scope. In this case, the law is worthless. Consumers wouldn't be able to tell between what is Creek or what is Chickasaw or what is Cherokee, and no one would trust their arts anymore as authentic. That is destruction of consumer confidence and defeats any ability to build a stable market for Southeast Indian arts like which exists in the Southwest; like what the Pueblo Indians enjoy because of the stringent laws that New Mexico has built up to protect them.

Anyway, I just wanted to pass along to you my two cents from an emerging Caddo artist as I start to see and understand the landscape of Native Arts in the Southeast. It is starting to grow and become more popular, but it has not embraced the protections that the Southwest saw they needed to install. Thank you. 


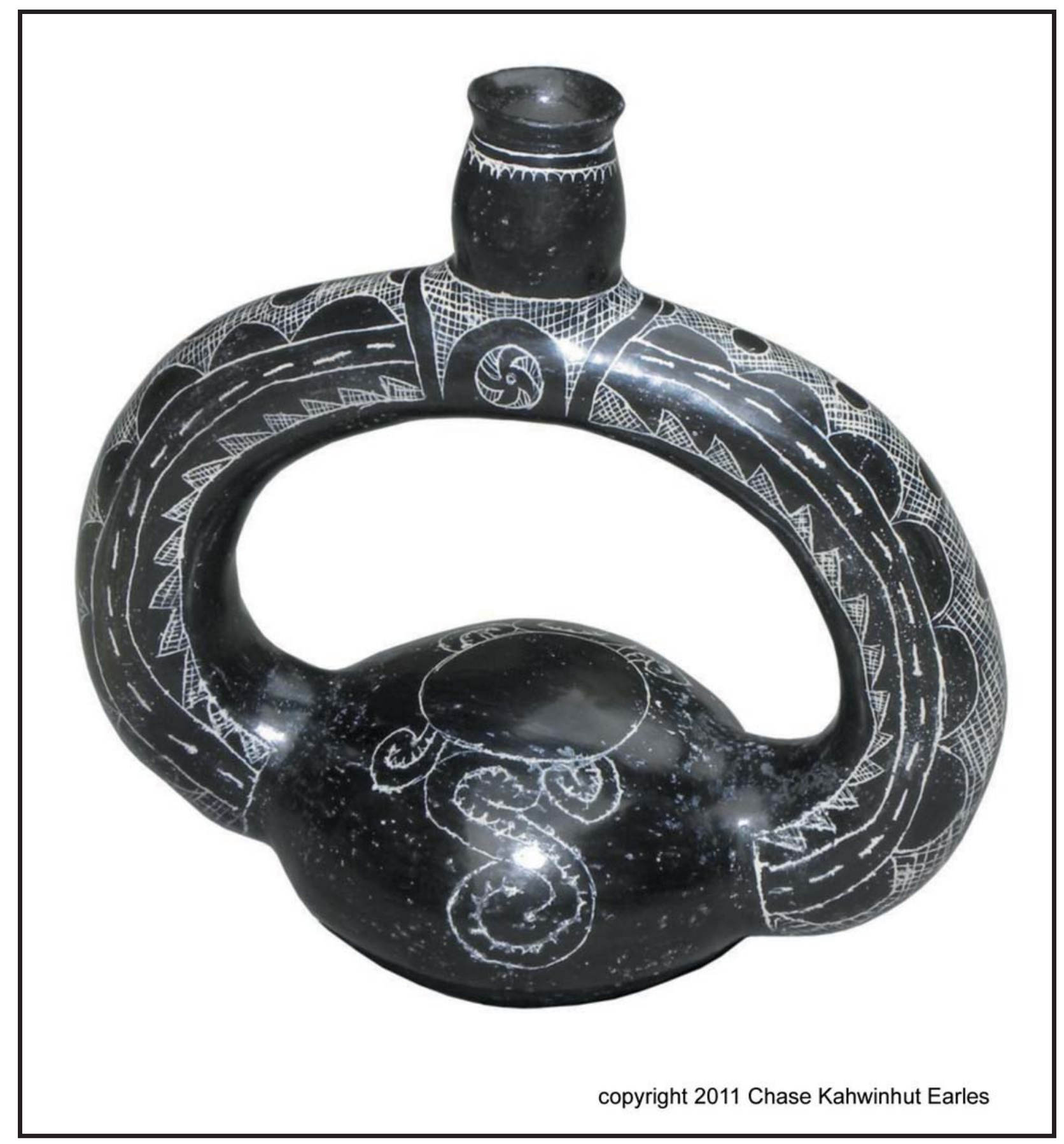

Figure 1. Koo-Dah-Do-uh-Sin “One Foot over Another" Stirrup Pot by Chase KahWinHut Earles. Engraved after firing. 


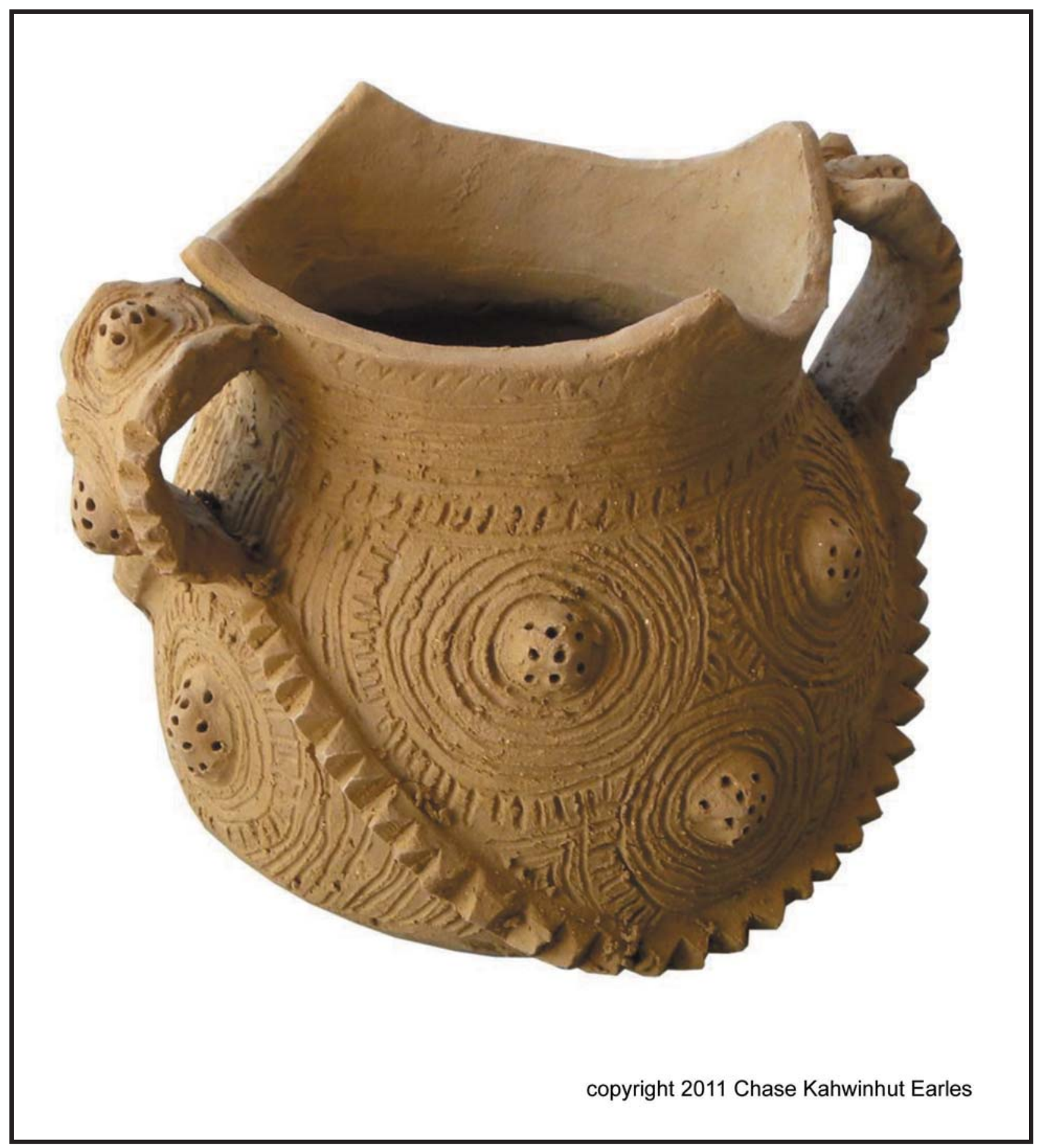

Figure 2. Haley Complicated Incised by Chase KahWinHut Earles. Handmade clay from creek bed. Traditional pit firing. 


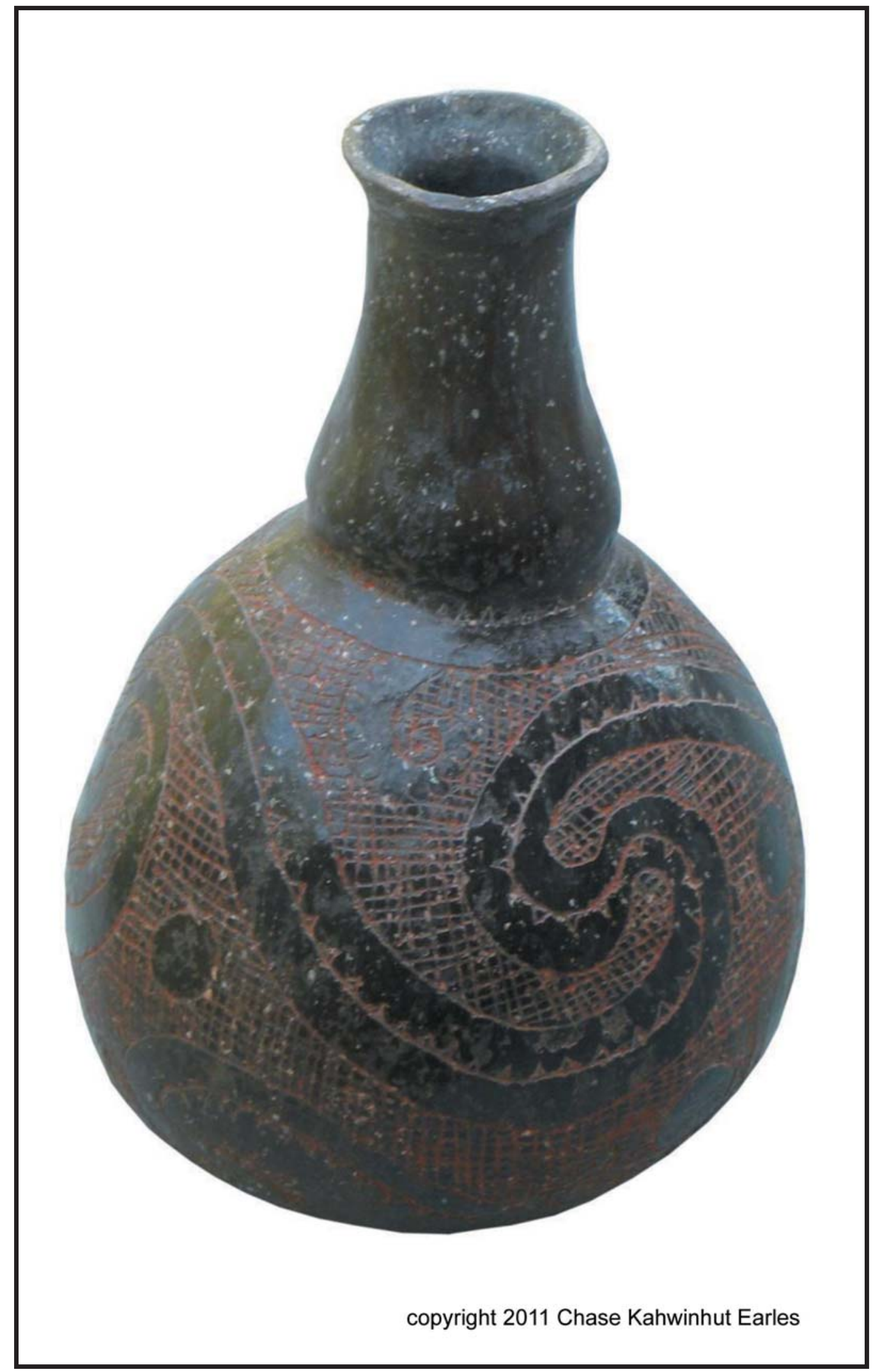

Figure 3. Nish "Moon", Hodges Engraved by Chase KahWinHut Earles. Handmade clay from Red River and mussel shell. Traditional pit fired. 


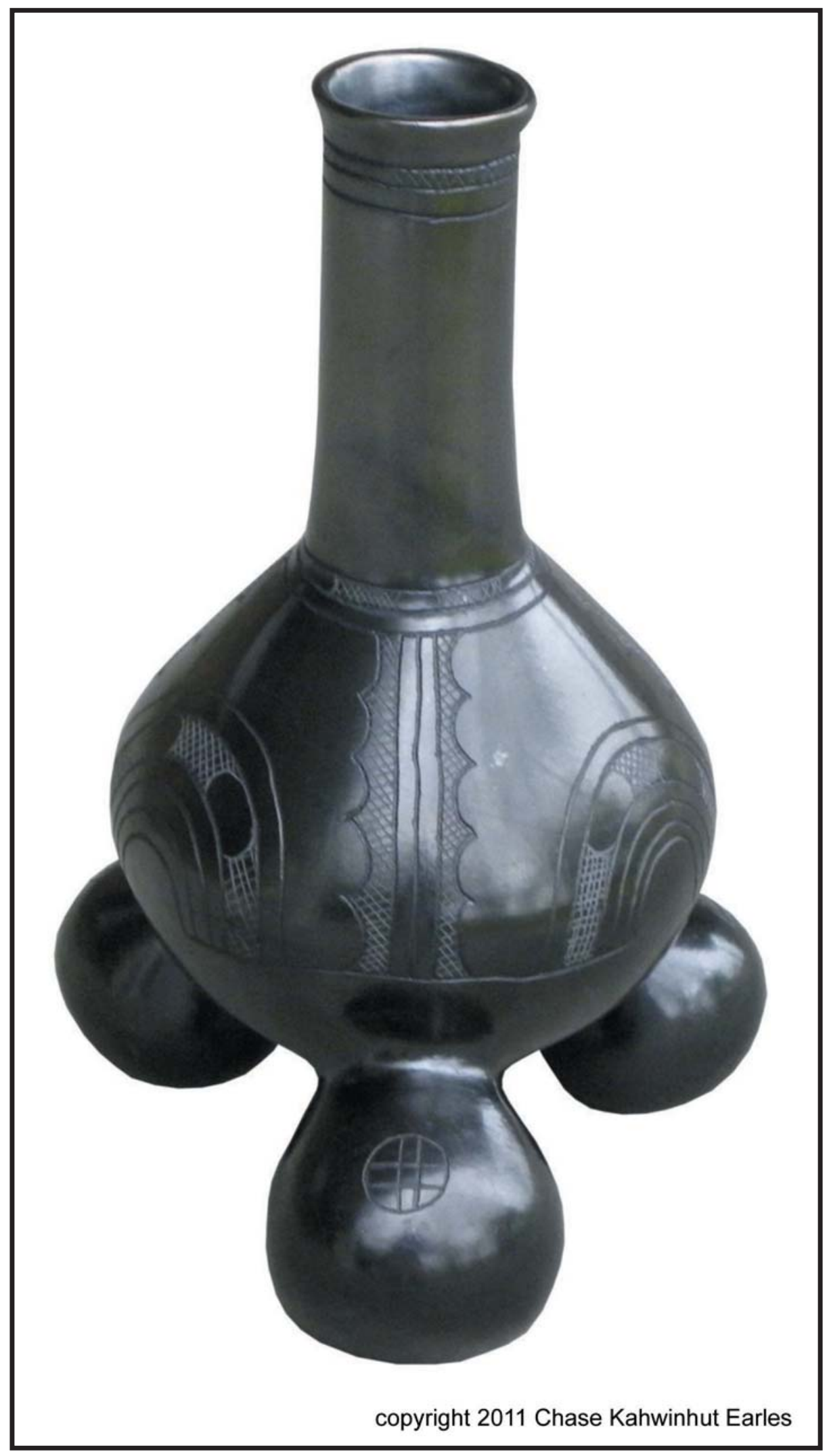

Figure 4. Bus-kah-noo "Grey Horse”, Friendship Engraved tripod by Chase KahWinHut Earles. 


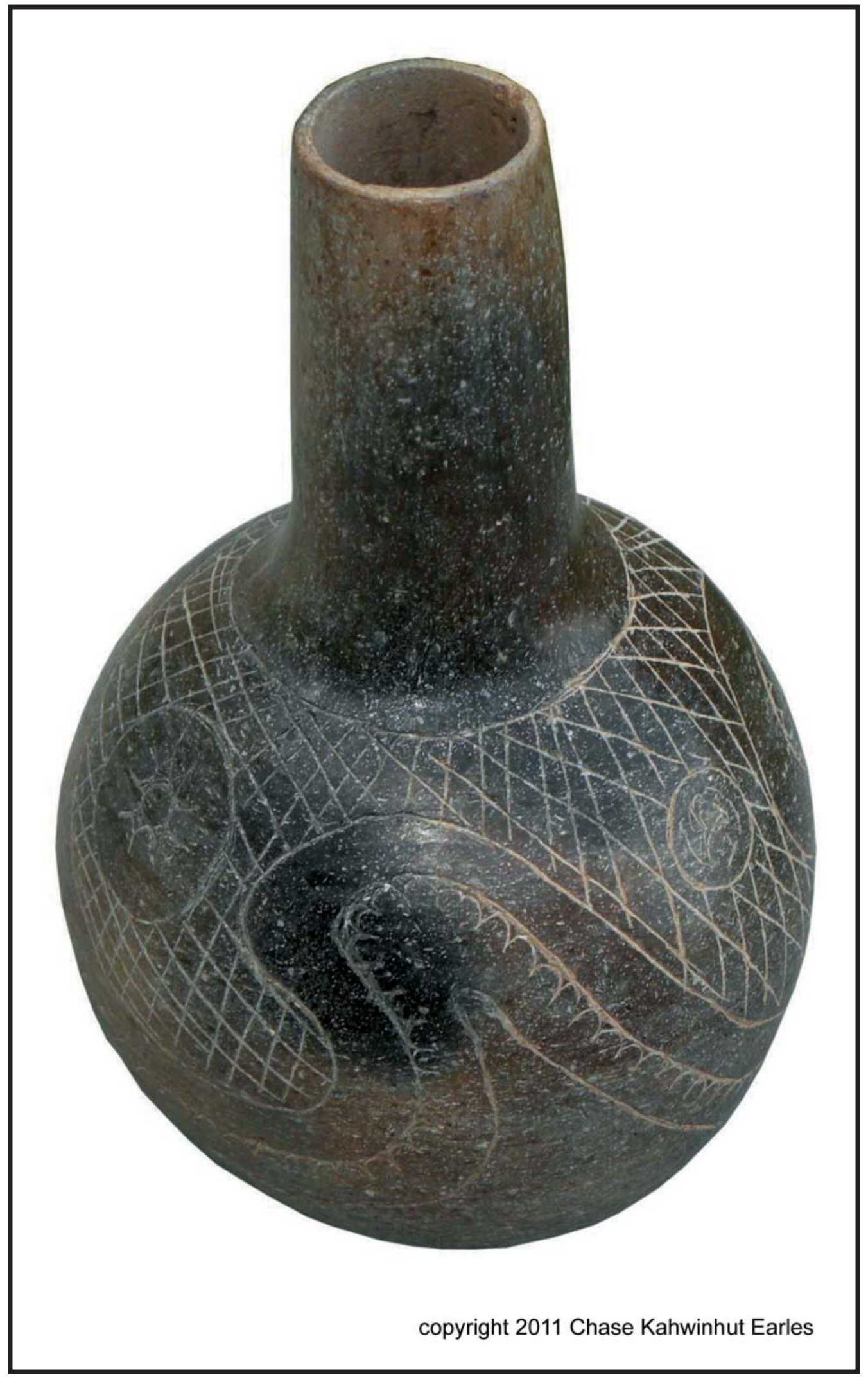

Figure 5. Nih-dah-hih "River", Hodges Engraved by Chase KahWinHut Earles. Handmade clay from the White River, Arkansas. Traditional pit fired. 


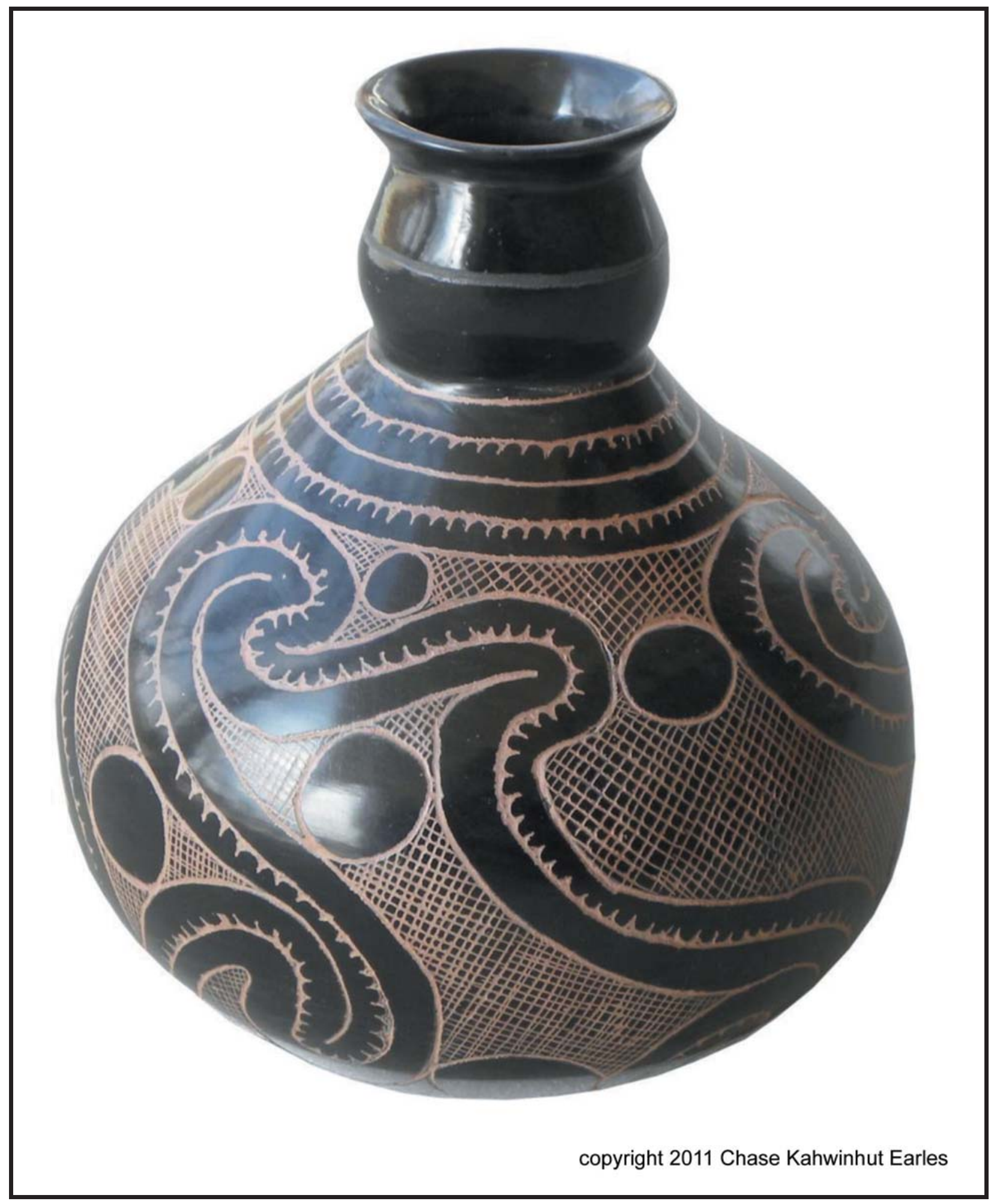

Figure 6. Kah-kee-bin-ayah-teno "Red Ribbons”, Natchitoches Engraved by Chase KahWinHut Earles. 